\title{
THE IMPACT OF APPLYING BASE ISOLATOR IN HOSPITAL BUILDING
}

\author{
Predaricka Deastra ${ }^{1}$, Jati Sunaryati ${ }^{2}$ dan Riza Aryanti ${ }^{3}$
}

\begin{abstract}
Due to Indonesia's location in the earthquake zone, it is necessary for civil engineers in Indonesia to study seismic performance of a building, which is strongly related to the structure of the building itself. Buildings equipped with vibration damping structures, known as an isolation system, will have a different seismic behavior than if it did not have one. This is due to the impact of an earthquake dampening vibration isolator. This final project analyzes the difference between seismic performance of a building using a seismic isolation system and ones without. The conclusion of this final project shows that the isolation system will decrease the internal force of a structure element by about $57.71 \%$ for axial force, $84.10 \%$ for shear, and $85.75 \%$ for moment. The application of an isolation system will also decrease the relative displacement by about $74,28 \%$ and extended structure vibration period by about $171.17 \%$.
\end{abstract}

Keyword: earthquake, seismic performance, isolation system.

\section{INTRODUCTION}

In Indonesian civil engineering, it is necessary for researchers to investigate the seismic performance of buildings, referring to the responses and behaviors of buildings to earthquakes. The seismic performance of a building is, however, highly dependent on the structure of the building itself. Buildings equipped with vibration damping structures-also known as isolation systemswill have a different seismic performance compared to buildings without isolation systems due to the impact of isolators in absorbing shockwaves from an earthquake. An example of an isolation system is called a base isolator.

Hospitals provide vital services to the community, especially during or after a natural disaster, such as an earthquake. Therefore it is essential for hospital buildings to be protected against earthquakes to ensure victims are adequately accommodated for when in need of necessary medical care. However, there are numerous hospital buildings in Indonesia that have not yet applied a base isolator, and the Obstetric, Children and Haemodialysis Inpatient Wards in DR. M. Djamil Hospital in Padang is an example. One way for this hospital to be safe against earthquakes is by applying a base isolator in the construction. Therefore, an analysis of the impact of applying a base isolator in hospital buildings should be conducted to show its significant reductions in the internal force, relative displacement, and its extension of the structure's vibration period during earthquakes. The analysis of the effects of the use of base isolators in the Obstetric, Children and Hemodialysis Inpatient Wards in DR. M. Djamil Hospital aims to compare the seismic performances of buildings

\footnotetext{
${ }^{1}$ Undergraduate Student, Civil Engineering Department, Faculty of Engineering, Andalas University

${ }^{2}$ Lecture, Civil Engineering Department, Faculty of Engineering, Andalas University

${ }^{3}$ Lecture, Civil Engineering Department, Faculty of Engineering, Andalas University
} 
fitted with and without base isolators. The analysis was carried out by measuring the displacement reduction value, internal force, and increase in vibration period induced by the use of base isolators; and by comparing those values to buildings without base isolators.

The result of this research will be very beneficial to engineers designing buildings as it can be taken into consideration when deciding whether or not to use base isolators. It can also be used as a reference for engineers to calculate the possible reduction of the dimensions of the structure.

\section{LITERATURE REVIEW}

Numerous studies on the effect of the use of base isolators have been done by employing different methods. In general, most of the research conducted focused on the response of the studied structure to earthquakes. One such research was performed by Dekker and Donna (2011) on Hotel Bumi Minang building and Donna (2011) on a polytechnic building. The results of their research showed a reduction in the internal force over $80 \%$ and a reduction of the relative displacement exceeding 70\%. Research regarding structural response only yielded results in the form of reductions in internal forces and relative displacement. Further research on the effects of the use of base isolators should be done to determine the seismic performance of buildings. The seismic performance of a structure is shown in the form of a hysteresis curve on a base shear versus displacement graph. To obtain such data, the earthquake load used as input in the analysis must be a cyclic load.

One analysis method that uses alternating earthquake load is Time History Analysis. Dynamic analysis of non-linear time history is suitable to analyze the effects of earthquakes on irregular structures. As it is difficult to precisely estimate the ground motion caused by an earthquake at a certain location, the required data was approximated by using simulated ground motion. One study that used the Time History Analysis method was a study conducted by Mehmet Komur et all., 2011. The research was conducted on isolated and fixed base structures of a four story building that used the seismic records of the Erzincan E-W, EW Marmara E-W, and Dusce W-S earthquakes in Turkey. The results produced are shown in a displacement versus building heights graph, and a base shear force versus time graph shown as follows:

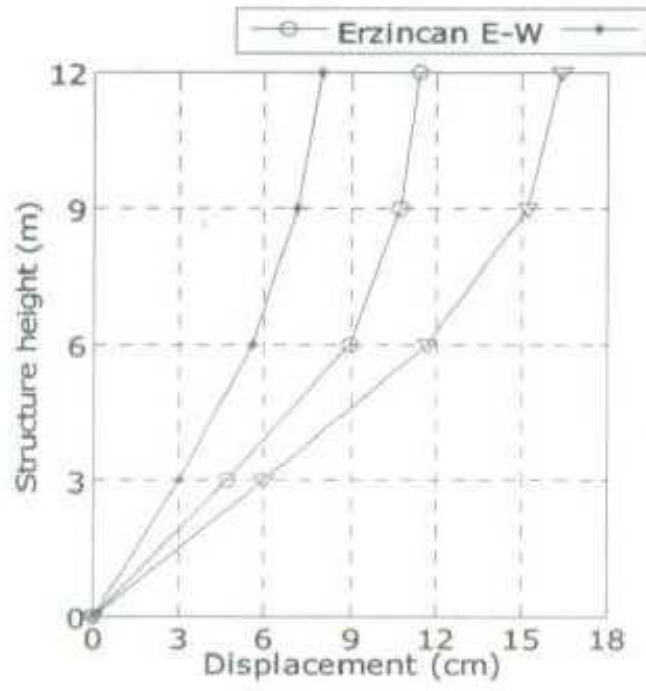

a)Fixed Base

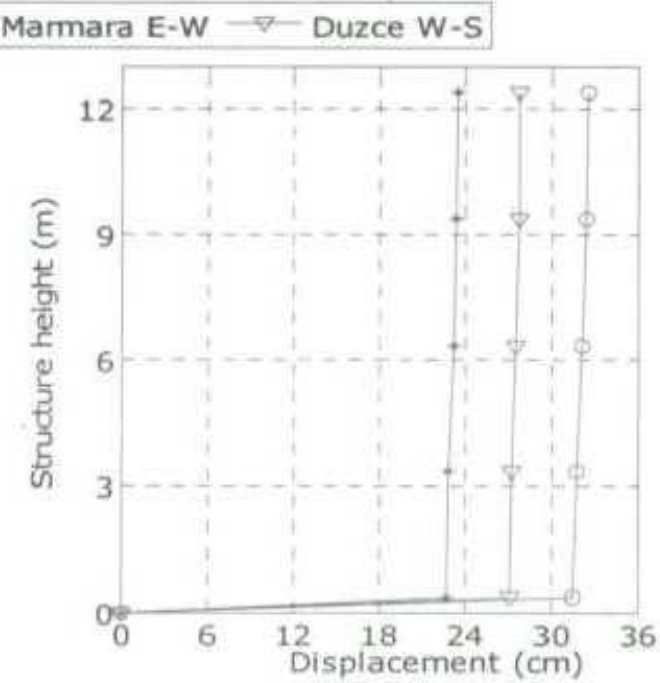

b) LRB

Figure 2.1 Various displacements for every 4-storyheights.

(Source : Mehmet et all ., 2011) 


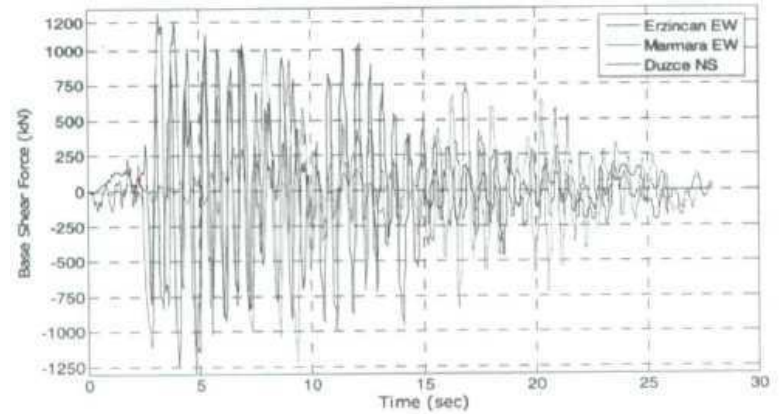

a) Fixed-base

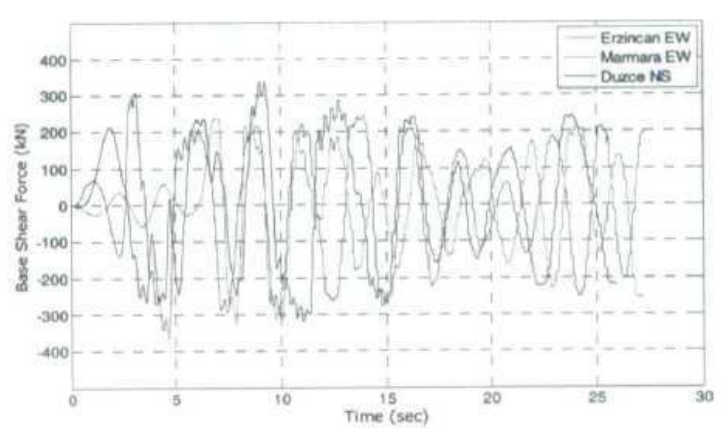

b) LRB

Figure 2.2 Various base shear forces versus time for 4-story buildings.

(Source : Mehmet et all ., 2011)

From the base shear force versus time graph, noticeable differences were observed between the structure fitted with a base isolator (b) and the structure without a base isolator (a), shown by weaker vibrations experienced by the former. This shows the effect of the base isolator application on the structure when rocked by an earthquake. Ideally, the input used for a building seismic performance analysis should originate from a seismic recording of an accelogram in the region of the structure. However, due to the unavailability of a seismic recording in Indonesia, the input data of this research was obtained from seismic recordings available in other parts of the world (Teddy Boen., 2007). Below is the list of the global earthquake data records from different places:

Table 2.1 list of earthquake data records from different sources in the world.

\begin{tabular}{|l|l|l|l|l|l|}
\hline $\begin{array}{l}\text { Location of } \\
\text { Earthquakes }\end{array}$ & Date & Fault Type & Magnitude & $\begin{array}{l}\text { Epicenter } \\
\text { Distance } \\
(\mathrm{km})\end{array}$ & Depth $(\mathrm{km})$ \\
\hline Chi-Chi, Taiwan & $20-09-1999$ & Thrust fault & 7.62 & 7.64 & 6.8 \\
\hline $\begin{array}{l}\text { El-Centro (Imperial } \\
\text { Valley), US }\end{array}$ & $19-05-1940$ & Strike Slip fault & 6.95 & 12.99 & 8.8 \\
\hline Kobe, Japan & $16-01-1995$ & Strike Slip fault & 6.9 & 18.27 & 17.9 \\
\hline Loma Prieta, US & $18-10-1989$ & Reverse fault & 6.93 & 28.64 & 17.5 \\
\hline Northridge, US & $17-01-1994$ & Thrust fault & 6.69 & 10.91 & 17.5 \\
\hline San Fernan do, US & $09-02-1971$ & Reverse fault & 6.61 & 11.86 & 13 \\
\hline Tabas, Iran & $16-09-1978$ & Thrust fault & 7.35 & 55.24 & 5.8 \\
\hline
\end{tabular}

(Source : Boen, 2007)

\section{STRUCTURE DESCRIPTION}

The object of this research is as follows:

1. The structure studied was the Obstetric, Children and Hemodialysis Inpatient Wards in DR. M. Djamil Hospital Padang block C S1, which consists of two parts, namely:

a. The upper structure which is the main building.

b. The lower structures which constitute the foundation of the building.

2. The modeling of the structure was carried out in three dimensions using the following loads:
a. dead load
b. live load
c. earthquake load

3. An analysis of the seismic performance was performed using the Time History Analysis method, utilizing Structure Analysis Program (SAP) 2000 software.

4. The technical data of the Obstetric, Children and Hemodialysis Inpatient Wards in DR. M. Djamil Hospital is as follows: 
Type of structure : Reinforced Concrete

Concrete quality :

a. Upper structure: K-300 and K-400

b. Lower structure: K-450

Steel Quality : fy 400 and $240 \mathrm{MPa}$

Building functions : Hospital

Number of floors $\quad: 5$ floors

Height of building $\quad: 10,465 \mathrm{~m} 2$

Type of foundation : mini pile

\section{METHODOLOGY}

\subsection{Time History Analysis}

Dynamic time history method is suitable to analyze the effects of earthquakes on buildings. As the earthquake ground motion at a site is difficult to estimate precisely, the required data can be approximated by using a simulated ground motion analysis. In this analysis, ground motion acceleration caused by an earthquake was used as input data. The seismic ground motion recordings were obtained from the accelogram of the El-Centro NS earthquake recorded on May 15, 1940. Figure 4.1 shows the data entry process imputed into the SAP 2000 software. In this analysis, the scale factor used was 1.6. This figure was derived from the multiplication of the acceleration of gravity (g) by ( $/ \mathrm{R}$ ), where $\mathrm{R}$ is the earthquake damping factor (in this case, full ductility $\mathrm{R}=8.5$ ), and I is the primacy factor of the building (1.4). To be able to enter the Time History earthquake loads into SAP2000, the ground motion data must first be defined in the Time History Case. For an output duration of 40 seconds with an interval of 0.01 seconds, the amount of the output steps was $40 / 0.1=4000$. The data is entered into SAP2000 for a Time History in the X (U1) and Y (U2) directions as shown in Figure 4.2:

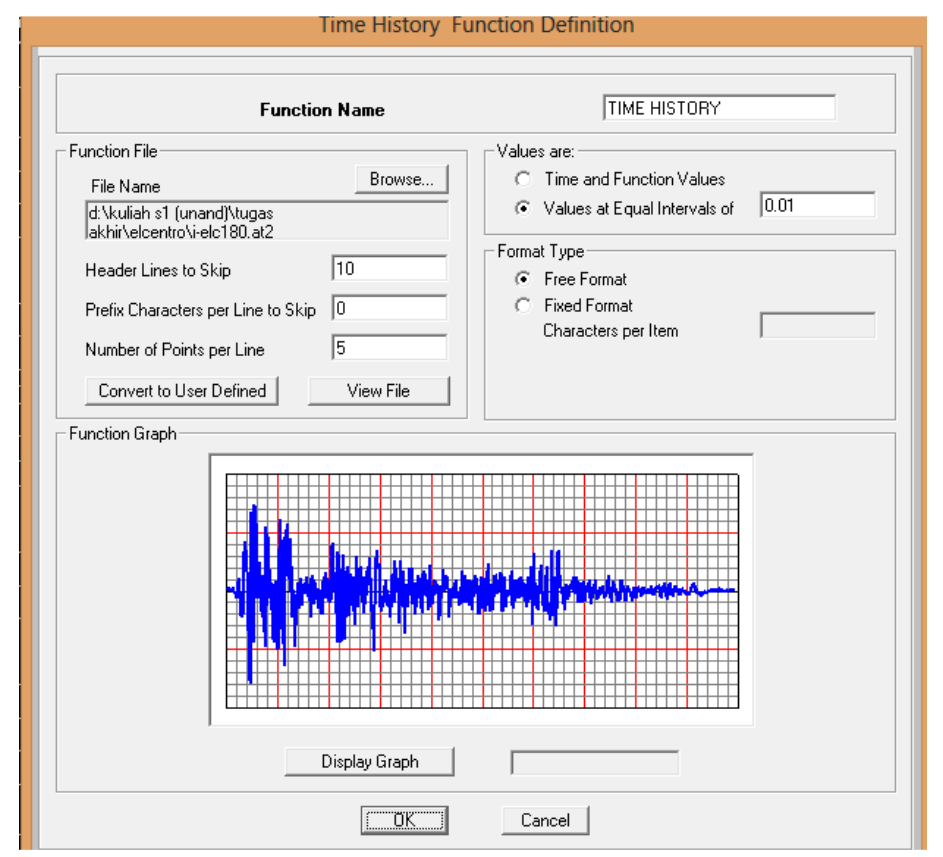

Figure 4.1 Elcentro Data Input

After defining the Time History Case and other variables an analysis of a building without base isolators-also known as a fixed base structure-was performed. 


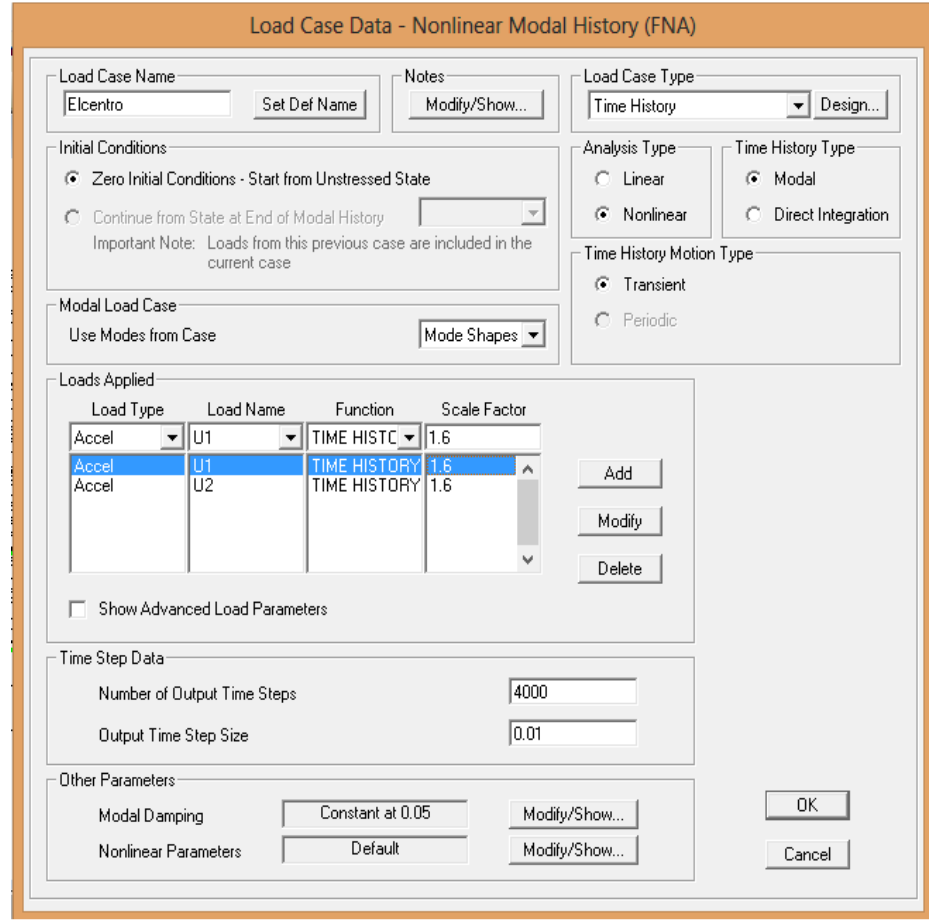

Figure 4.2 Time History data input

\subsection{Fixed Base Structure}

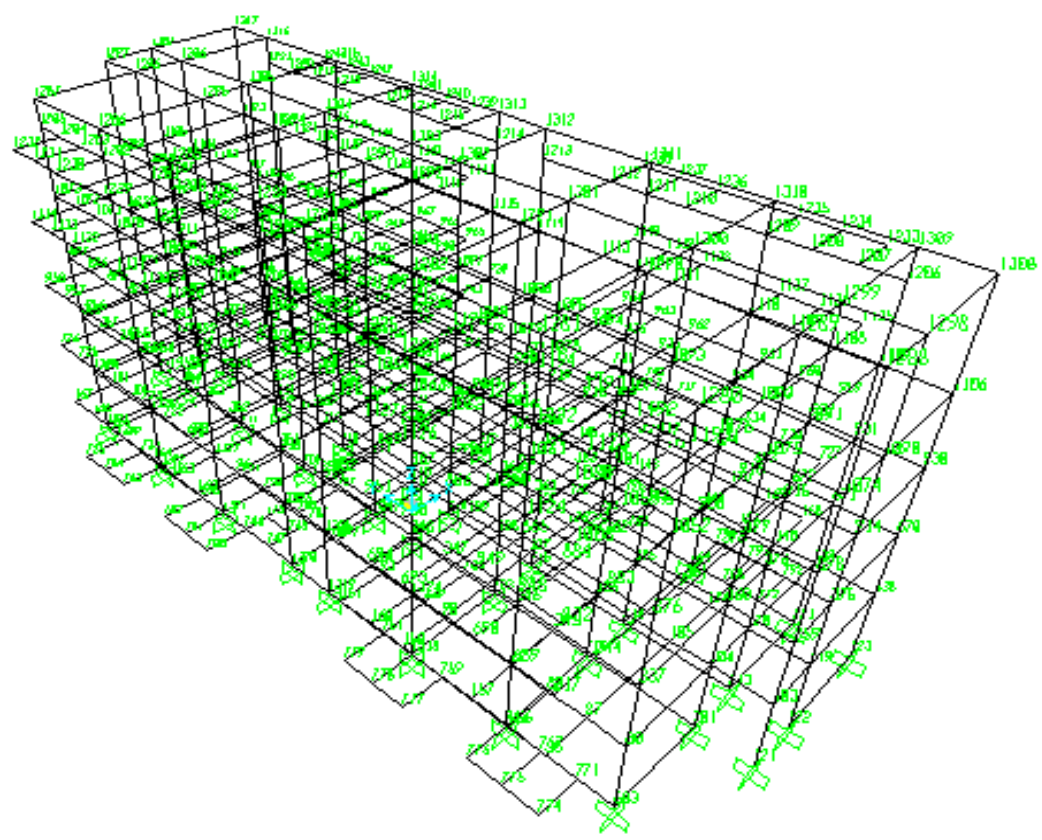

Figure 4.3 Fixed Base Structure

An analysis of a fixed base structure was carried out prior to any analysis of buildings fitted with base isolators to determine the joint reactions. The joint reactions of each column in the building were then used to determine the properties of the base isolator that would be used. Table 4.1 summarizes the reactions of each column in the base story caused by a combination of loads. 
Table 4.1 Joint Reactions of the side columns

\begin{tabular}{|c|c|c|}
\hline Joint ID & $\begin{array}{l}\text { Grid } \\
\text { Location }\end{array}$ & $\begin{array}{l}\text { Joint Reactions } \\
(\mathrm{kN})\end{array}$ \\
\hline 121 & A-5 & 1163.816 \\
\hline 122 & A-6 & 943.078 \\
\hline 123 & A-7 & 771.345 \\
\hline 211 & $\mathrm{~T}-5$ & 817.446 \\
\hline 212 & $\mathrm{~T}-6$ & 1305.58 \\
\hline 213 & $\mathrm{~T}-7$ & 1065.385 \\
\hline 683 & B-2 & 1341.493 \\
\hline 701 & B-5 & 1448.777 \\
\hline 712 & S-5 & 1625.266 \\
\hline 721 & B-7 & 1640.283 \\
\hline 728 & $\mathrm{I}-7$ & 1288.519 \\
\hline 729 & $\mathrm{~J}-7$ & 1573.073 \\
\hline 731 & $\mathrm{~N}-7$ & 2398.143 \\
\hline 733 & P-7 & 2448.374 \\
\hline 736 & S-7 & 1328.14 \\
\hline 756 & G-7 & 2425.321 \\
\hline 763 & E-2 & 2398.409 \\
\hline 764 & E-7 & 2448.091 \\
\hline 1318 & G-2 & 2410.852 \\
\hline 1319 & $\mathrm{I}-2$ & 1553.263 \\
\hline 1320 & $\mathrm{~J}-2$ & 1403.971 \\
\hline 1321 & $\mathrm{~N}-2$ & 2500.799 \\
\hline 1322 & P-2 & 2430.989 \\
\hline 1323 & S-2 & 1181.99 \\
\hline
\end{tabular}

Table 4.2 Joint Reactions of the center columns

\begin{tabular}{|l|l|l|}
\hline Joint ID & $\begin{array}{l}\text { Grid } \\
\text { Location }\end{array}$ & $\begin{array}{l}\text { Joint Reactions } \\
(\mathrm{kN})\end{array}$ \\
\hline 702 & E-5 & 1913.933 \\
\hline 703 & G-5 & 1951.397 \\
\hline 705 & $\mathrm{I}-5$ & 1806.316 \\
\hline 706 & $\mathrm{~J}-5$ & 1625.67 \\
\hline 709 & $\mathrm{~N}-5$ & 2010.945 \\
\hline 711 & P-5 & 1911.356 \\
\hline 713 & B-6 & 1756.986 \\
\hline 714 & E-6 & 1964.499 \\
\hline 715 & G-6 & 1956.449 \\
\hline 716 & $\mathrm{I}-6$ & 1565.527 \\
\hline 717 & $\mathrm{~J}-6$ & 1873.133 \\
\hline 718 & $\mathrm{~N}-6$ & 1953.942 \\
\hline 719 & P-6 & 1956.88 \\
\hline 720 & S-6 & 1435.882 \\
\hline
\end{tabular}

From the tables above, the maximum joint reactions of both side and center columns were determined.

\begin{tabular}{|l|l|}
\hline Column Location & Maximum Joint Reaction $(\mathrm{kN})$ \\
\hline Side Column & 2500.799 \\
\hline Center Column & 2010.945 \\
\hline
\end{tabular}

The next stage of the process was to select the properties of the base isolator that would be used based on the maximum joint reaction of the columns.

\section{4 | JURNAL REKAYASA SIPIL}


The base isolators used for the fixed base structure were Bridgestone Japan products of type $\mathrm{H}$ Bearing High Damping Rubber Bearings (HDRB). Based on the joint reactions, the selected properties of the base isolators used were as follows:

\begin{tabular}{|l|l|}
\hline Column Location & Base Isolator's Properties \\
\hline Side Column & HH065X6R \\
\hline Center Column & HH065X6R \\
\hline
\end{tabular}

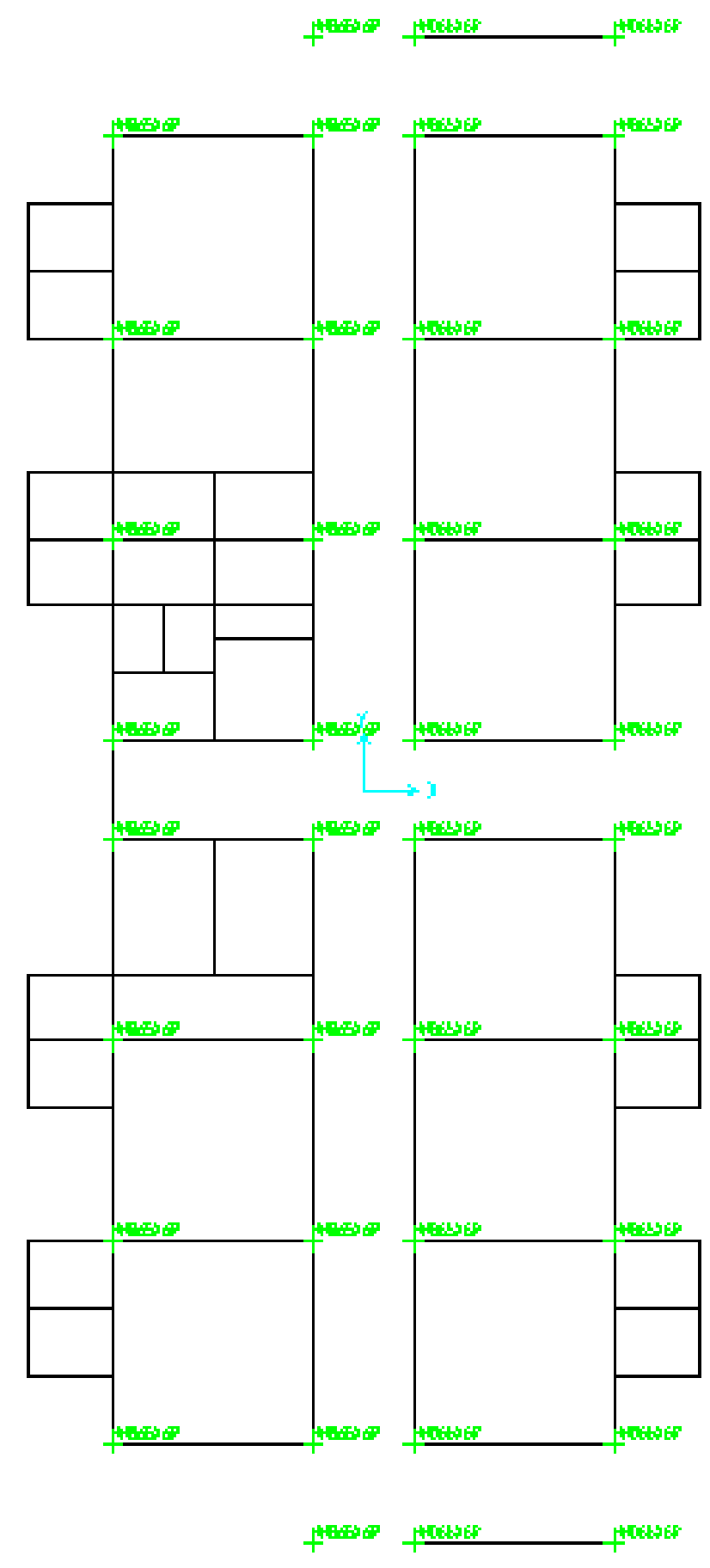

Figure 4.4 Location of Base Isolators 


\subsection{Base Isolated Structure}

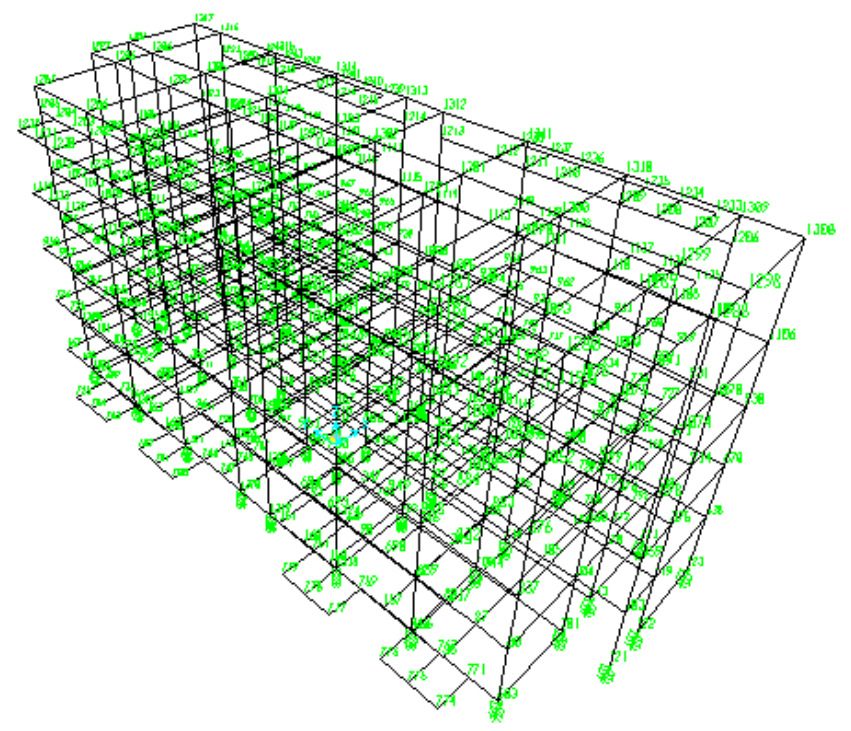

Figure 4.5 Base Isolated Structure

The next step was the selection of the beam, column and joint that would serve as a sample in the internal force output.

\subsection{Sample of Joint and Frame}

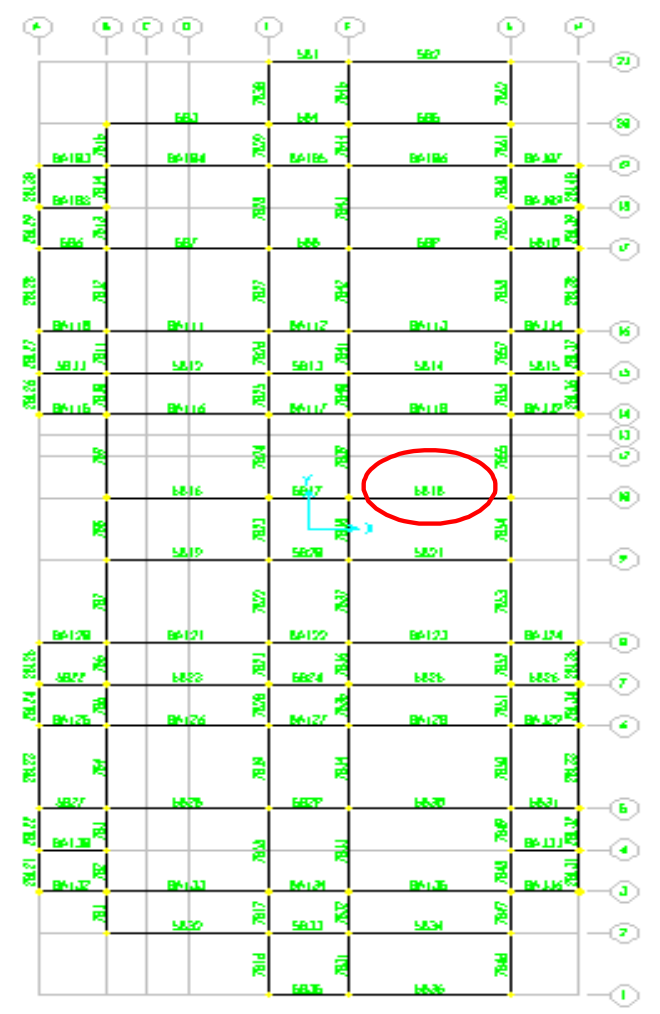

Figure 4.6 Beams for internal force output. 


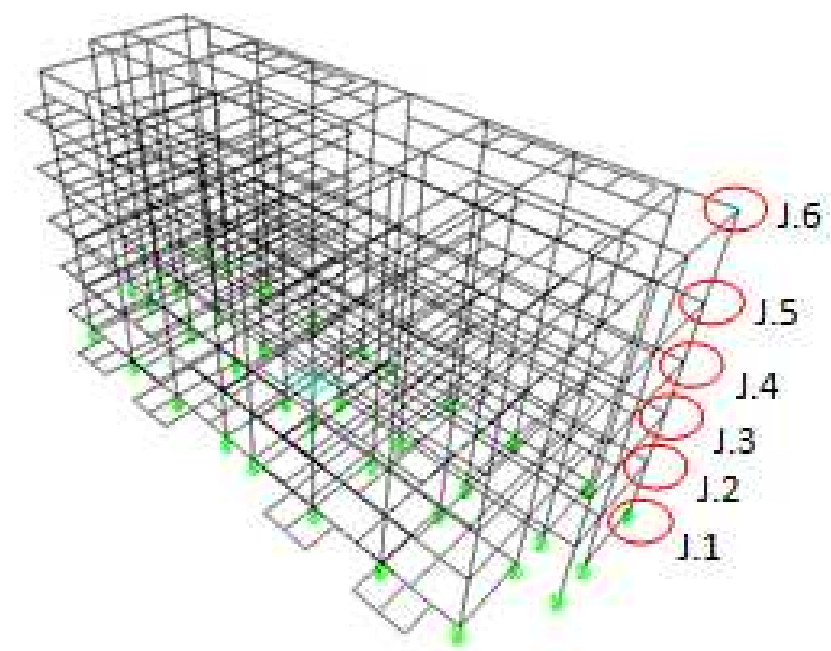

Figure 4.7 Joints for displacement output for each story

Table 4.3 Joints for displacement output for each story

\begin{tabular}{|l|l|l|}
\hline Joint & Locations & Story \\
\hline J.6 & G1 & 6 \\
\hline J.5 & G1 & 5 \\
\hline J.4 & G1 & 4 \\
\hline J.3 & G1 & 3 \\
\hline J.2 & G1 & 2 \\
\hline J.1 & G1 & 1 \\
\hline
\end{tabular}

Table 4.4 Beams for internal force output

\begin{tabular}{|l|l|l|}
\hline Frame Label & Description & Storey \\
\hline 5B18 & Beam & 5 \\
\hline 4B80 & Beam & 4 \\
\hline 2B18 & Beam & 3 \\
\hline DK23 & Column & 1 \\
\hline DK24 & Column & 1 \\
\hline DK25 & Column & 1 \\
\hline
\end{tabular}

Subsequently, an analysis of the selected beam, column and joint was conducted for both base isolated and fixed base structures. 


\section{ANALYSIS AND DISCUSSION}

\subsection{Comparison of the Seismic Performances of Fixed Based and Base Isolated Structures}

\section{Displacement}

The results of the joint analysis are shown in the following Time History graphs:

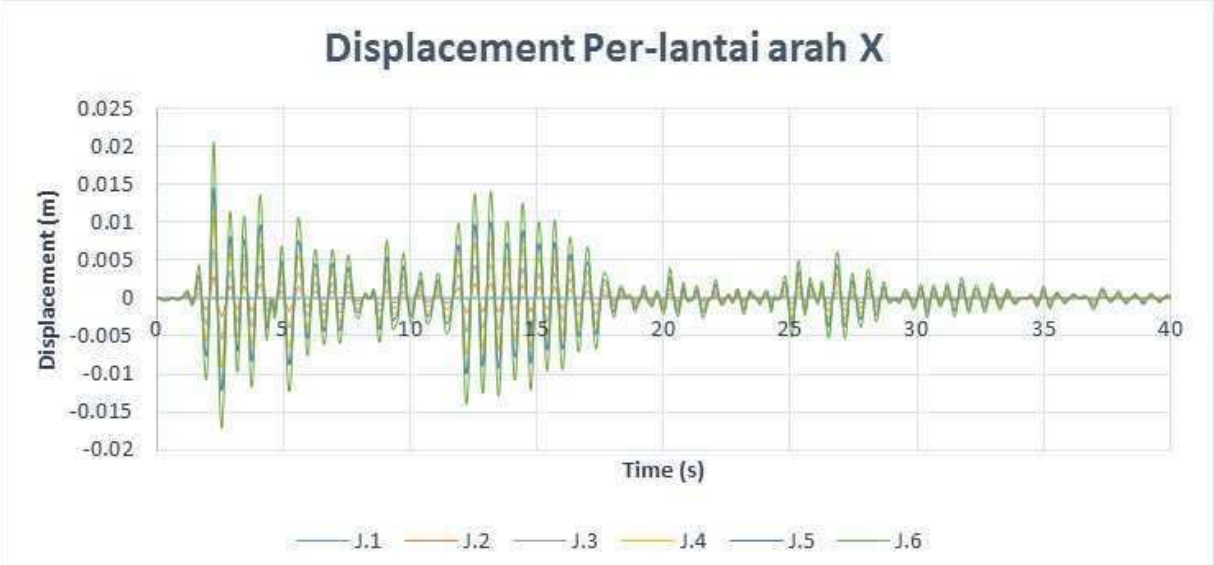

Figure 5.1 Output graph of the Displacement in the $\mathrm{X}$ direction for the fixed base structure

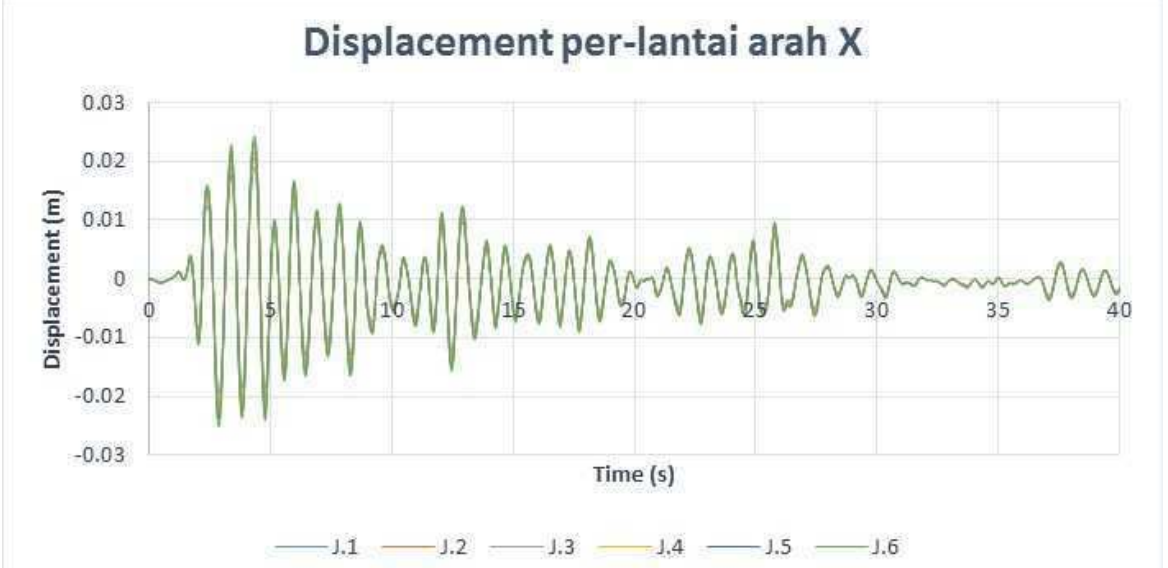

Figure 5.2 Output graph of the Displacement in the $\mathrm{X}$ direction for the base isolated structure

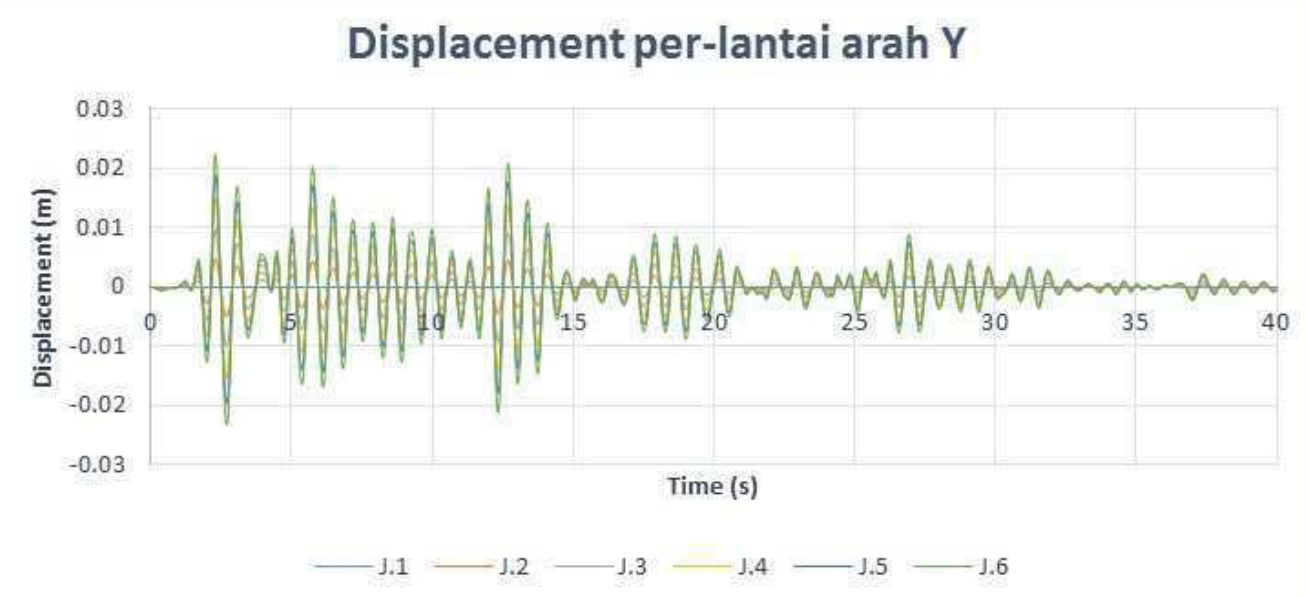

Figure 5.3 Output graph of the Displacement in the $\mathrm{Y}$ direction for the fixed base structure 


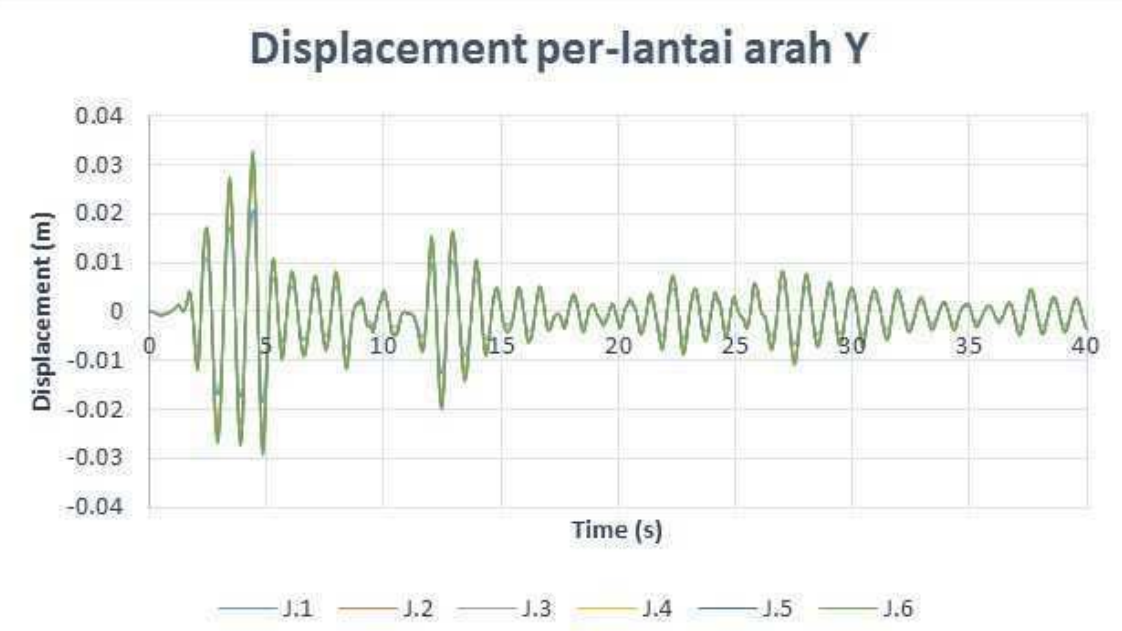

Figure 5.4 Output graph of the Displacement in the Y direction for the base isolated structure

From Figure 5.1 and 5.2, it can be observed that the maximum displacement in the $\mathrm{X}$ direction of the fixed base structure occurred on the J.6 joint (on the rooftop) with a value of $0.02061 \mathrm{~m}$ or \pm 2 $\mathrm{cm}$. This value was gained at $\mathrm{t}=2.25$ seconds. On the other hand, the maximum displacement in the $\mathrm{X}$ direction of the base isolated structure also occurred on the J.6 joint (on the rooftop) with a value of $0.0243 \mathrm{~m}$ or $\pm 2.4 \mathrm{~cm}$. This maximum displacement occurred at 4.34 seconds. It appeared that the maximum displacement of the base isolated structure was higher than that of the fixed base structure. However, the inter-story drift (or relative displacement) of the base isolated structure was much smaller than that of the fixed base structure.

Table 5.1 Comparison of the maximum displacement values for each story in the $\mathrm{X}$ direction

\begin{tabular}{|l|l|l|}
\hline Story & $\begin{array}{l}\text { Fixedbase } \\
(\mathrm{cm})\end{array}$ & $\begin{array}{l}\text { BaseIsolated } \\
(\mathrm{cm})\end{array}$ \\
\hline 1 & 0 & 1.9 \\
\hline 2 & 0.284 & 2.059 \\
\hline 3 & 0.647 & 2.163 \\
\hline 4 & 1.086 & 2.259 \\
\hline 5 & 1.464 & 2.332 \\
\hline 6 & 2.061 & 2.43 \\
\hline
\end{tabular}

Tabel 5.2 Inter-story Drift for each story in the X direction

\begin{tabular}{|l|l|l|}
\hline Story & $\begin{array}{l}\text { Fixedbase } \\
(\mathrm{cm})\end{array}$ & $\begin{array}{l}\text { BaseIsolated } \\
(\mathrm{cm})\end{array}$ \\
\hline $1-2$ & 0.284 & 0.159 \\
\hline $2-3$ & 0.363 & 0.104 \\
\hline $3-4$ & 0.439 & 0.096 \\
\hline $4-5$ & 0.378 & 0.073 \\
\hline $5-6$ & 0.597 & 0.098 \\
\hline Total & 2.061 & 0.53 \\
\hline
\end{tabular}

The relative displacement of the fixed base structure was $2.061 \mathrm{~cm}$, while the value for the base isolated structure was $0.53 \mathrm{~cm}$. This means that the use of base isolation reduced the relative displacement by $74.28 \%$. The graphs of displacement in the $\mathrm{Y}$ direction (Figure 5.3 and 5.4) demonstrate maximum displacement of the fixed base structure on the J.6 joint (on the rooftop) with a value of $0.02244 \mathrm{~m}$ or \pm 2.2 centimeters. This maximum value occurred at 2.29 seconds. For the base isolated structure, the maximum displacement occurred on the J.6 joint (on the rooftop) with a value of $0.03296 \mathrm{~m}$ or $\pm 3.3 \mathrm{~cm}$. This maximum value occurred at 4.41 seconds. As of the displacement in the $\mathrm{X}$ direction, the base isolated structure exhibited a larger maximum 
displacement value in the $\mathrm{Y}$ direction, but it was a much smaller relative displacement value compared to the fixed base structure.

Table 5.3 Comparison of the maximum

\begin{tabular}{|l|l|l|}
\hline Story & $\begin{array}{l}\text { Fixedbase } \\
(\mathrm{cm})\end{array}$ & $\begin{array}{l}\text { BaseIsolated } \\
(\mathrm{cm})\end{array}$ \\
\hline 1 & 0 & 2.082 \\
\hline 2 & 0.48 & 2.76 \\
\hline 3 & 0.976 & 2.937 \\
\hline 4 & 1.487 & 3.091 \\
\hline 5 & 1.899 & 3.206 \\
\hline 6 & 2.244 & 3.296 \\
\hline
\end{tabular}

Tabel 5.4 Inter story Drift in the Y direction

\begin{tabular}{|l|l|l|}
\hline Story & $\begin{array}{l}\text { Fixedbase } \\
(\mathrm{cm})\end{array}$ & $\begin{array}{l}\text { BaseIsolated } \\
(\mathrm{cm})\end{array}$ \\
\hline $1-2$ & 0.480 & 0.678 \\
\hline $2-3$ & 0.496 & 0.177 \\
\hline $3-4$ & 0.511 & 0.154 \\
\hline $4-5$ & 0.412 & 0.115 \\
\hline $5-6$ & 0.345 & 0.09 \\
\hline Total & 2.244 & 1.214 \\
\hline
\end{tabular}

The relative displacement of the fixed base structure was $2.244 \mathrm{~cm}$, while the value for the base isolated structure was $1.214 \mathrm{~cm}$. The reduction in the relative displacement due to base isolators reached $45.9 \%$. Below is the graph of maximum displacements for each story in the $\mathrm{X}$ and $\mathrm{Y}$ directions:
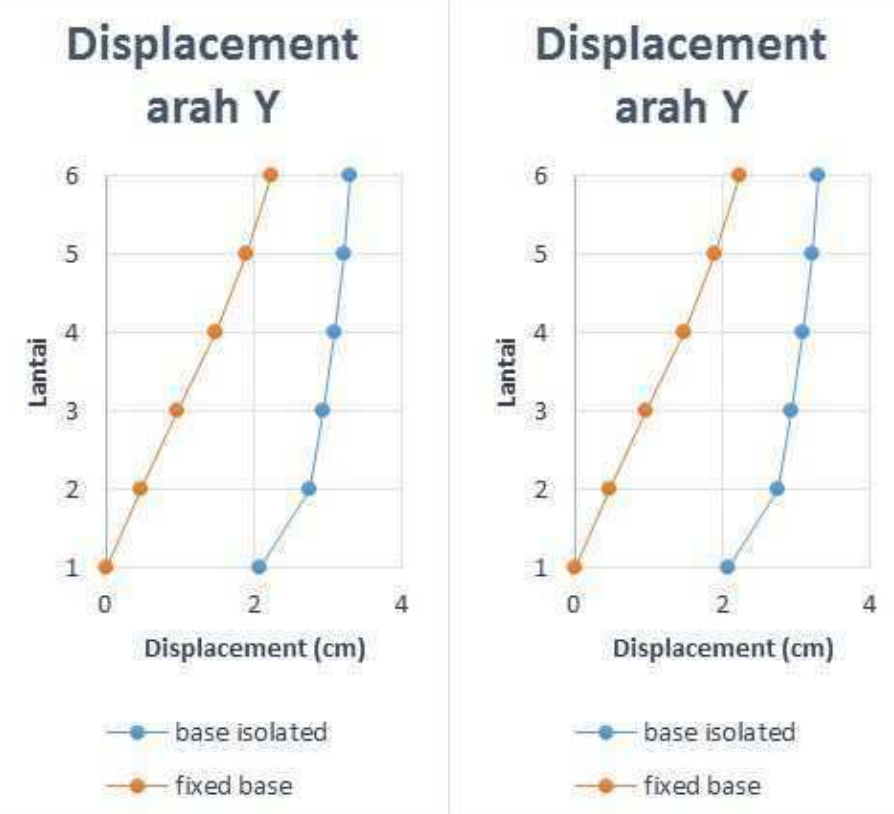

Figure 5.5 Displacement for each story on $\mathrm{X}$ and $\mathrm{Y}$ directions.

The above graph shows that the base isolated structure exhibited a displacement on the ground floor (base) as the base isolator caused the structure to move as a single unit (represented as a straight line in the graph). 


\section{Internal Force}

Analysis of the internal force demonstrated a significant reduction, as shown in the following tables:

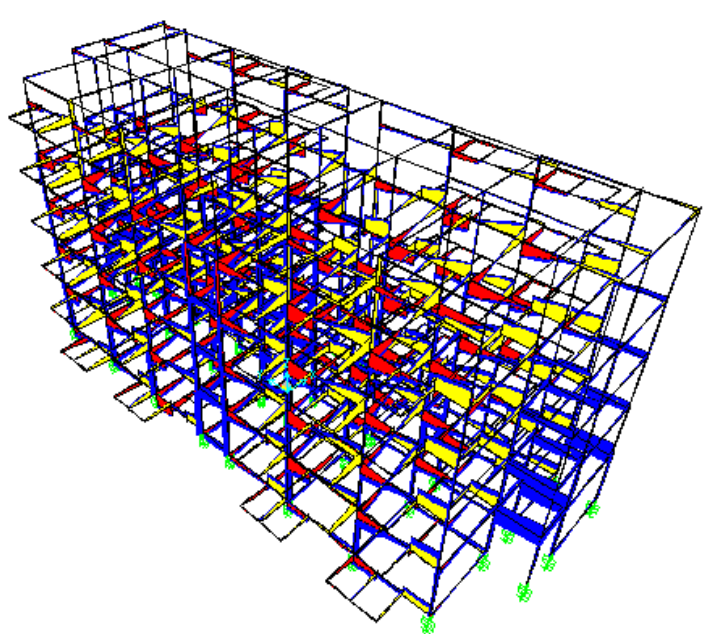

Figure 5.6 Share force in base isolated structure

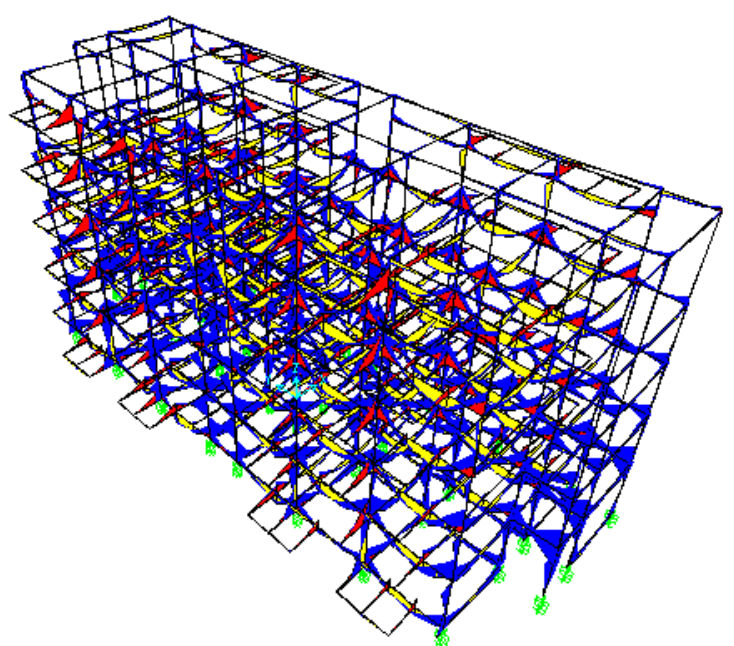

Figure 5.7 Moment in base isolated structure

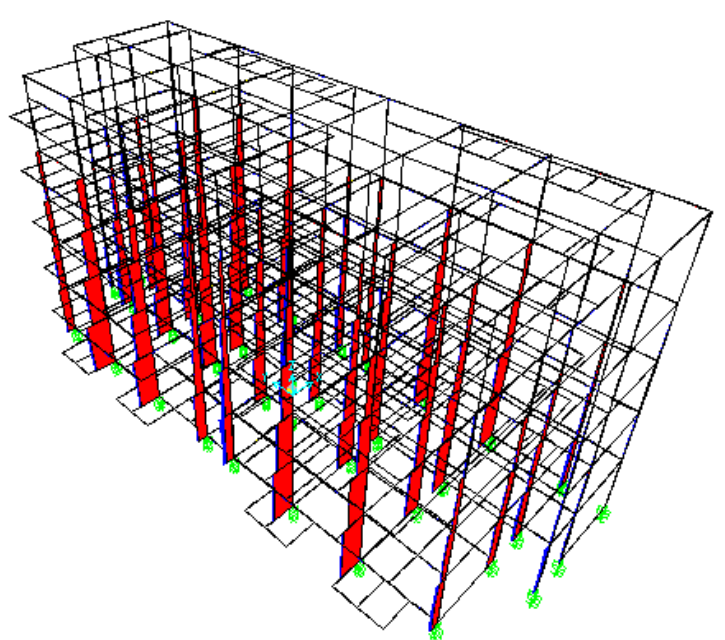

Figure 5.8 Axial force in base isolated structure 
Table 5.5 Maximum Internal Force in the beams of the fixed base structure

\begin{tabular}{|l|l|l|l|}
\hline $\begin{array}{l}\text { Frame } \\
\text { Label }\end{array}$ & $\begin{array}{l}\text { Axial } \\
(\mathrm{kN})\end{array}$ & $\begin{array}{l}\text { Shear } \\
(\mathrm{kN})\end{array}$ & $\begin{array}{l}\text { Moment } \\
(\mathrm{kNm})\end{array}$ \\
\hline $5 \mathrm{~B} 18$ & 39.809 & 130.476 & 174.301 \\
\hline $4 \mathrm{~B} 80$ & 12.745 & 148.723 & 251.003 \\
\hline 2B18 & 20.948 & 163.721 & 314.673 \\
\hline
\end{tabular}

Tabel 5.6 Maximum Internal Force in the beams of the base isolated structure

\begin{tabular}{|l|l|l|l|}
\hline $\begin{array}{l}\text { Frame } \\
\text { Label }\end{array}$ & $\begin{array}{l}\text { Axial } \\
(\mathrm{kN})\end{array}$ & $\begin{array}{l}\text { Shear } \\
(\mathrm{kN})\end{array}$ & $\begin{array}{l}\text { Moment } \\
(\mathrm{kNm})\end{array}$ \\
\hline $5 \mathrm{~B} 18$ & 30.358 & 106.075 & 106.251 \\
\hline $4 \mathrm{~B} 80$ & 10.76 & 108.315 & 121.701 \\
\hline 2B18 & 8.859 & 106.413 & 126.911 \\
\hline
\end{tabular}

Figure 5.7 Moment in base isolated structure

\begin{tabular}{|l|l|l|l|}
\hline $\begin{array}{l}\text { Frame } \\
\text { Label }\end{array}$ & $\begin{array}{l}\text { Axial } \\
(\mathrm{kN})\end{array}$ & $\begin{array}{l}\text { Shear } \\
(\mathrm{kN})\end{array}$ & $\begin{array}{l}\text { Moment } \\
(\mathrm{kNm})\end{array}$ \\
\hline DK23 & 1449.46 & 114.625 & 304.1133 \\
\hline DK24 & 1478.234 & 113.863 & 302.091 \\
\hline DK25 & 1734.336 & 114.826 & 302.5672 \\
\hline
\end{tabular}

Table 5.8 Maximum Internal Force in the columns of the base isolated structure

\begin{tabular}{|l|l|l|l|}
\hline $\begin{array}{l}\text { Frame } \\
\text { Label }\end{array}$ & $\begin{array}{l}\text { Axial } \\
(\mathrm{kN})\end{array}$ & $\begin{array}{l}\text { Shear } \\
(\mathrm{kN})\end{array}$ & $\begin{array}{l}\text { Moment } \\
(\mathrm{kNm})\end{array}$ \\
\hline DK23 & 1150.822 & 18.221 & 43.5811 \\
\hline DK24 & 1197.563 & 18.111 & 43.0496 \\
\hline DK25 & 1517.652 & 23.808 & 68.8114 \\
\hline
\end{tabular}

The graphs of the internal forces are shown below :

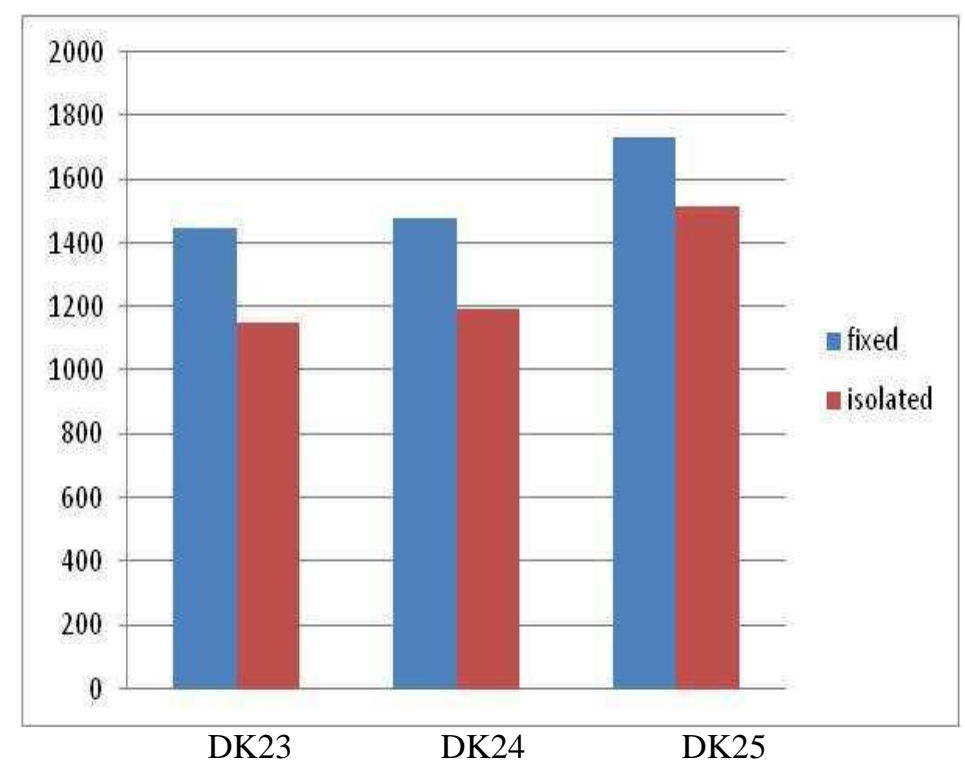

Figure 5.9 Axial force in Column 


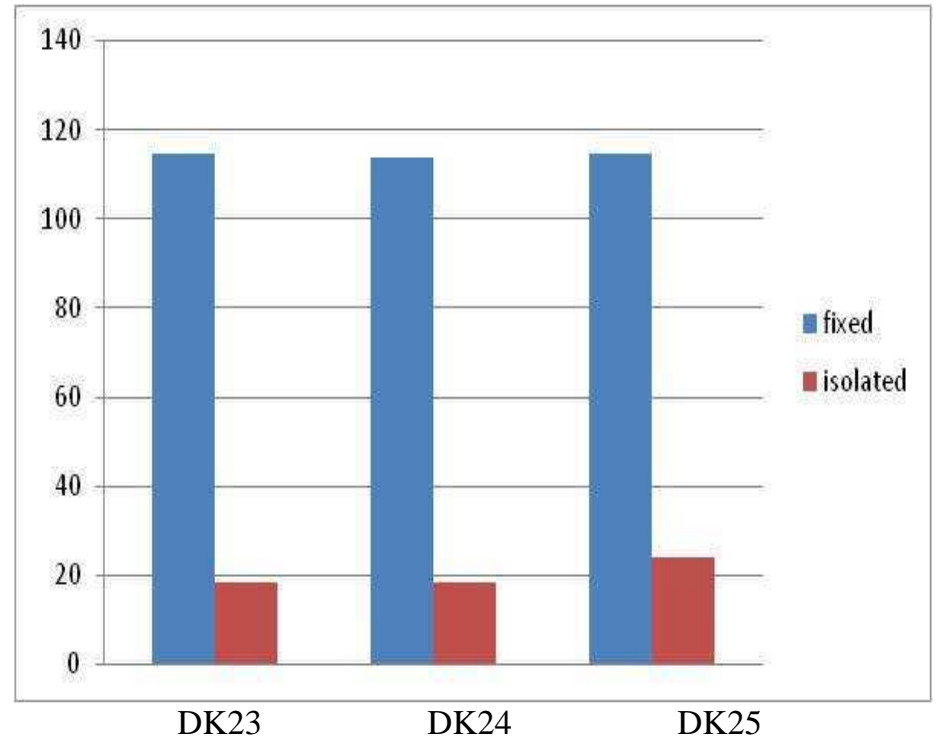

Figure 5.10 Shear in Columns

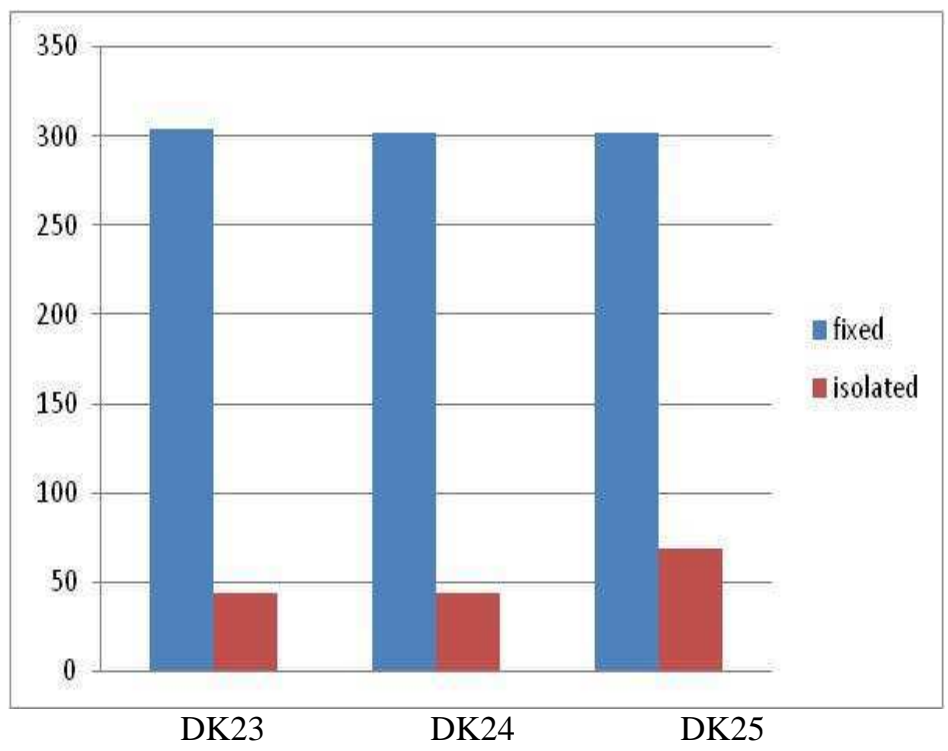

Figure 5.11 Moments in Columns

The tables and graphs above show a significant reduction in the internal forces of the base isolated structure compared to the fixed base structure. The internal forces of the beams appeared as follows: the reduction reached $57.71 \%$ for the axial force, $35.01 \%$ for the shear force, and $59.67 \%$ for the moment. As for the internal forces of the columns: the reduction reached $20.60 \%$ for the axial force, $84.10 \%$ for the shear force, and $85.75 \%$ for the moment.

\section{Vibration Period}

From the time history graphs (Figures 5.1-5.4), it can be seen that the vibrations experienced by the fixed base structure are of a higher frequency than that of the base isolated structure. 


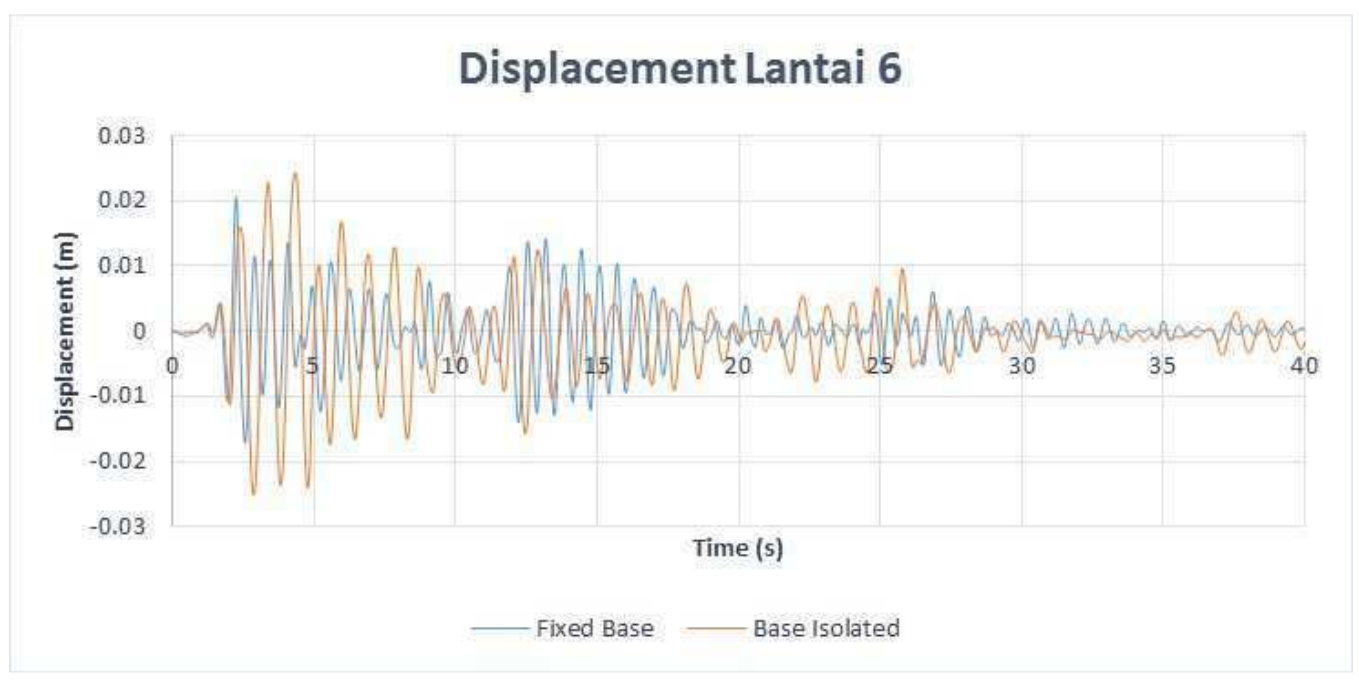

Figure 5.12 Time History graph for joint1308 (top floor)

This means that the period of vibration of the fixed base structure was lower than the period of vibration of the base isolated structure.

Table 5.9 Vibrating Period of Structures

\begin{tabular}{|l|l|l|l|}
\hline \multirow{3}{*}{$\begin{array}{l}\text { Mode } \\
\text { Shape }\end{array}$} & \multicolumn{2}{|l|}{$\begin{array}{l}\text { VibratingPeriod } \\
\text { (second) }\end{array}$} & \multirow{2}{*}{ \%of enhancement } \\
\cline { 2 - 4 } & $\begin{array}{l}\text { Fixed } \\
\text { Base }\end{array}$ & $\begin{array}{l}\text { Base } \\
\text { Isolated }\end{array}$ & \\
\hline 1 & 0.7223 & 1.73468 & 140.16 \\
\hline 2 & 0.62251 & 1.6881 & 171.17 \\
\hline 3 & 0.60353 & 1.60893 & 166.58 \\
\hline 4 & 0.41965 & 0.55239 & 31.63 \\
\hline 5 & 0.41765 & 0.46758 & 11.95 \\
\hline
\end{tabular}

The greater the vibration period of the structure, the better it is to withstand an earthquake.

\section{ANALYSIS AND DISCUSSION}

The conclusions of this study are as follows:

1. The use of base isolators can reduce the internal force of both beams and columns. The reductions in the internal force of beams are as follows: up to $57.71 \%$ for the axial force, $35.01 \%$ for the shear force, and $59.67 \%$ for the moment; while for columns: up to $20.60 \%$ for the axial force, $84.10 \%$ for the shear force, and $85.75 \%$ for the moment.

2. The use of base isolators can reduce the relative displacement for each story in both the $\mathrm{X}$ and Y directions as much as $74.28 \%$ and $45.9 \%$, respectively.

3. The use of base isolators can extend the period of vibration up to $171.17 \%$.

The results of this research showed that there were substantial reductions in the internal force, relative displacement, and vibration period due to the use of base isolators. Therefore, in subsequent studies, analysis of structures such as beams and columns should be conducted to determine the reduction in the dimensions and reinforcements of base isolated buildings. 


\section{REFERENCE}

Boen, Teddy (Senior Advisor WSSI (World Seismic Safety Initiative)). 2007.Engineering Non-engineered buildings, from Non-Engineered to 3D Non-Linear Analysis, Performance Based Design. Papers.

Komur,Mehmet., Karabok, Turan.,and Deneme,Ibrahim.2011. Nonlinear Dynamic Analysis of Isolated and Fixed-Base Reinforced Concrete Structures. Gazi University Journal of Science.

Kelly, M. James. 1991."Base Isolation: Origin sand Development,” EERC News,Vol.12, No.1, January 1991 Naeim, Farzad dan Kelly, M.James. 1999.Design of Seismic Isolated Structures : From Theory to Practice. California : John Wiley \& Sons, Inc

SNI03-1726-2003 : Tata Cara Perencanaan Ketahanan Gempa untuk Bangunan Gedung.

Sharma, Ajay dan Jangid R.S..2009.Behaviour of Base- Isolated Structures with High Initial Isolator Stiffness. International Journal of Engineering and Applied Sciences.

T.K.Datta. 2010. Seismic Analysis of Structure. Indian Institute of Technology Delhi, India 